\title{
Pengaruh Inflasi, Nilai Tukar, dan BI Rate terhadap Volume Pertumbuhan Emisi Sukuk Korporasi di Indonesia
}

\author{
Influence of inflation, kurs, and BI Rate on the volume of corporate sukuk emissions growth in \\ Indonesia
}

\section{Almayda Rakhmadita}

Program Studi D4 Keuangan Syariah, Politeknik Negeri Bandung

E-mail: almaydarakhmadita@gmail.com

\section{Destian Arshad Darulmalshah Tamara}

Jurusan Akuntansi, Politeknik Negeri Bandung

E-mail: destian.arshad@polban.ac.id

\section{Benny Barnas}

Jurusan Akuntansi, Politeknik Negeri Bandung

E-mail: benny.barnas@polban.ac.id

\begin{abstract}
The purpose of this study is to analyze macroeconomic indicators that affect the growth volume of corporate sukuk emissions in Indonesia. Macroeconomic indicators used in this study are inflation, exchange rates and the BI rate. So the research object examined by the author is Inflation (X1), Kurs (X2), andBI Rate (X3) as independentvariables and Corporate Sukuk. Emissions in Indonesia (Y) as the dependent variable. The method used in this study is a quantitative research method with a descriptive approach. The author selects companies that issue corporate sukuk in Indonesia as a research sample. The data used in this study are secondary data on capital market statistics for the 2014-2018 period downloaded Otoritas Jasa Kenangan (OJK) website. The research model used is multiple linear regression analysis using windows-based data processing applications. The results of this study are that inflation has a negative and significant effect on the Growth Volume of Corporate Sukuk Emissions in Indonesia, Exchange Rate has a positive and significant effect on the Growth Volume of Corporate Sukuk Emissions in Indonesia, and the BI Rate does not significantly influence the Growth Volume of Corporate SukukEmissions in Indonesia.
\end{abstract}

Keywords: corporate sukuk, inflation, kurs, BI rate.

\section{Pendahuluan}

Di Indonesia pasar modal terdiri dari dua jenis, ada pasar modal konvensional dan pasar modal syariah. Di dalam pasar modal syarah terdapat salah satu instrumen atau alternatif investasi yang disebut dengan sukuk. Sukuk terdiri dari 2 macam, ada sukuk korporasi dan SBSN atau yang biasa disebut dengan Surat Berharga Syariah Nasional. Sejak tahun 2015 pasar modal syariah mulai ramai dan mulai banyak diminati, sebanyak 3,17 triliun rupiah nominal sukuk diterbitkan, peningkatan nominal penerbitan sukuk semakin meningkat setiap tahunnya. Ini memperlihatkan bahwa investasi keuangan yang cukup diminati investor di pasar modal syariah adalah sukuk. Sukuk banyak diminati oleh investor karena merupakan salah satu alternatif menarik yang dapat digunakan oleh investor untuk menanamkan modalnya. 
Tabel 1. Pertumbuhan Emisi Sukuk Korporasi

(dalam triliun rupiah)

\begin{tabular}{|c|c|}
\hline Tahun & Emisi Sukuk Korporasi \\
\hline 2014 & 0,92 \\
\hline 2015 & 3,17 \\
\hline 2016 & 4,32 \\
\hline 2017 & 6,50 \\
\hline 2018 & 10,26 \\
\hline
\end{tabular}

Sumber : Statistik Pasar Modal 2014-2018

Dilihat dari tabel diatas sukuk memang selalu mengalami kenaikan setiap tahunnya namun pertumbuhan sukuk masih belum sepesat pertumbuhan obligasi korporasi. (Suta, 2000) Kondisi pasar modal selalu mengalami pasang surut, hal ini menunjukkan bahwa aktifitas di pasar modal memiliki keterkaitan dengan kondisi ekonomi makro. Dalam kegiatan ekonomi makro terkandung aspek produksi, pendapatan, pengeluaran, anggaran nasional, jumlah uang beredar, neraca pembayaran, dan kebijakan moneter. Kondisi ekonomi makro yang stabil merupakan energi pendorong bagi berkembangnya pasar modal.

Sukuk atau obligasi syariah merupakan salah satu bentuk investasi. Investasi merupakan sebuah kegiatan ekonomi yang biasanya banyak dipengaruhi oleh kondisi makroekonomi. Kondisi makroekonomi akan berpengaruh terhadap kegiatan serta perkembangan investasi. Beberapa variable makroekonomi yang akan dikaitkan dengan investasi tersebut antara lain inflasi, nilai tukar, dan BI rate.

Inflasi yaitu kenaikan tingkat harga yang terjadi secara terus menerus. Inflasi mempengaruhi individu, pengusaha, serta pemerintah. Di dalam investasi sangat penting untuk menurunkan inflasi karena peningkatan inflasi secara relative merupakan sinyal negatif bagi pemodal. Adanya fluktuasi pada nilai tukar akan menyebabkan investor berpikir kembali untuk menanamkan dananya ke dalam bentuk simpanan atau investasi (Tripuspitorini \& Setaiwan, 2020). BI rate merupakan suku bunga acuan yang mencerminkan sikap kebijakan moneter yang ditetapkan oleh Bank Indonesia. Jika BI rate selalu meningkat maka investor akan lebih memilih untuk menimpan modalnya ke dalam bentuk simpanan di pasar uang daripada menanamkan modalnya dalam bentuk investasi di pasar modal. Sebaliknya, jika BI rate terus menurun maka investor akan lebih memilih untuk menanamkan modalnya dalam bentuk investasi di pasar modal daripada menyimpan modalnya di pasar uang dalam bentuk simpanan.

\section{Kajian Pustaka}

\section{Pasar Modal}

Manan (2009) Pasar modal adalah sarana yang mempertemukan antara pihak yang memiliki kelebihan dana dengan pihak yang kekurangan dana, dimana dana yang diperdagangkan merupakan dana jangka panjang. Pasar modal memungkinkan perusahaan dapat memperoleh modal dari dana pinjaman maupun dana equity. Pasar modal terbagi menjadi pasar modal konvesional dan pasar modal syariah. Keduanya memiliki perbedaan dimana pasar modal syariah merupakan pasar modal yang dijalankan dengan prinsip syariah. Salah satu instrumen yang dapat digunakan perusahaan untuk memperoleh dana adalah sukuk 


\section{Pasar Uang}

Anoraga, Pandji dan Pakarti Piji (2001) pasar uang adalah suatu tempat pertemuan abstrak dimana para pemilik dana jangka pendek dapat menawarkan kepada calon pemakai yang membutuhkannya, baik secara langsung maupun melalui perantara. Sedangkan yang dimaksud dengan dana jangka pendek adalah dana-dana yang dihimpun dari perusahaan maupun perorangan dengan batasan waktu dari satu hari sampai satu tahun, yang dapat diperjualbelikan didalam pasar uang. Indikator pasar uaing sangat diperlukan untuk mengukur atau paling tidak mengamati perkembangan pasar uang, salah satu dari banyaknya indikator pasar uang yaitu Nilai Tukar.

\section{Sukuk}

Hariyanto (2017) Sukuk adalah istilah yang berasal dari bahasa Arab, yaitu dari kata 'Sakk' dengan bentuk jamaknya (plural) adalah 'Sukuk' yang berarti dokumen atau sertifikat. Pada abad pertengahan, sukuk lazim digunakan oleh para pedagang muslim sebagai dokumen yang menunjukkan kewajiban finansial yang timbul dari perdagangan dan aktivitas komersial lainnya. Menurut Fatwa Dewan Syariah Nasional No: 32/DSNMUI/IX/2002 tentang Obligasi Syariah adalah suatu surat berharga jangka panjang berdasarkan prinsip syariah yang dikeluarkan oleh emiten kepada pemegang obligasi syariah yang mewajibkan emiten untuk membayar pendapatan kepada pemegang obligasi syariah baik berupa bagi hasil, margin atau fee serta membayar dana pbligasi pada saat jatuh tempo.

Sukuk memiliki beberapa karakteristik, antara lain :

1. Merupakan bukti kepemilikan atas aset, hak manfaat, jasa atau kegiatan investasi tertentu.

2. Pendapatan yang diberikan berupa imbalan, margin, bagi hasil, sesuai dengan jenis akad yang digunakan dalam penerbitan.

3. Terbebas dari unsur riba, gharar, dan maysir.

4. Penerbitannya melalui special purpose vehicle (SPV).

5. Memerlukan adanya underlying asset.

6. Penggunaan proceeds harus sesuai prinsip syariah.

\section{Makroekonomi}

Mankiw (2007) Makroekonomi adalah studi tentang perekonomian secara menyeluruh, termasuk pertumbuhan pendapatan, perubahan harga, dan tingkat pengangguran.

\section{Inflasi}

Inflasi menurut Badan Pusat Statisitik Nasional adalah sebuah nilai ketika tingkat dari harga yang berlaku di dalam suatu bidang ekonomi. Inflasi merupakan salah satu indikator makroekonomi yang memiliki banyak dampak pada perokonomian di Indonesia. Sebagai salah satu dari indikator di dalam melihat kestabilitasian perekonomian satu wilayah tertentu, perkembangan harga jasa dan barang pada umumnya dapat dihitung melalui indeks harga dari para konsumen (Tripuspitorini \& Setiawan, 2020). Dengan demikian, angka inflasi amatlah mempengaruhi besar kecilnya produksi suatu barang.

\section{Nilai Tukar}

Mankiw (2007) nilai tukar (exchange rate) atau kurs antara dua negara adalah tingkat harga yang disepakati penduduk kedua negara untuk saling melakukan perdagangan. Menurut Bank Indonesia nilai tukar mata uang atau yang sering disebut dengan kurs adalah harga satu unit mata uang asing dalam mata uang domestik atau dapat juga dikatakan harga mata uang domestik terhadap mata uang asing (Rahmawati \& Djatnika, 2020) 


\section{BI Rate}

Sebagaimana yang disebutkan dalam Inflation Targeting Framework bahwa BI Rate merupakan suku bunga acuan Bank Indonesia dan merupakan sinyal (stance) dari kebijakan moneter Bank Indonesia. "BI Rate adalah suku bunga instrumen sinyaling Bank Indonesia yang ditetapkan pada RDG (Rapat Dewan Gubernur) triwulanan untuk berlaku selama triwulan berjalan (satu triwulan), kecuali ditetapkan berbeda oleh RDG bulanan dalam triwulan yang sama". (Bank indonesia dalam Inflation Targeting Framework). (Siamat, 2005) BI Rate adalah suku bunga dengan tenor satu bulan yang diumumkan oleh Bank Indonesia secara periodik untuk jangka waktu tertentu yang berfungsi sebagai sinyal (stance) kebijakan moneter. Salah satu manfaat dari adanya BI Rate bagi Perekonomian Nasional adalah untuk menentukan jenis-jenis investasi yang akan memberi keuntungan kepada para pengusaha apabila tingkat pengembalian modal yang mereka peroleh melebihi tingkat bunga

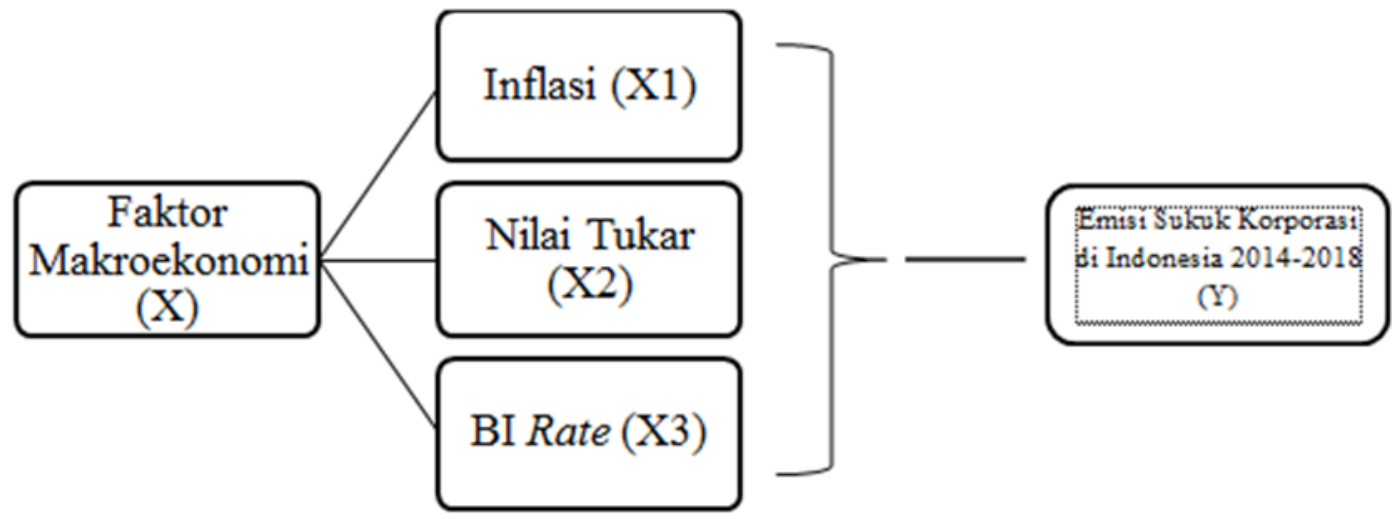

Gambar 1. Hubungan antara Emisi Sukuk Korporasi di Indonesia dengan Inflasi, Nilai Tukar, dan BI Rate.

\section{Metode Penelitian}

Metode penelitian yang digunakan oleh penulis yaitu menggunakan penelitian yang bersifat deskriptif dengan pendekatan kuantitatif. Analisis deskriptif digunakan untuk memberikan gambaran secara umum mengenai bagaimana pertumbuhan sukuk korporasi di Indonesia serta menjelaskan bagaimana pengaruh makroekonomi di Indonesia khususnya untuk indikator inflasi, nilai tukar, dan juga BI rate. Analisis deskriptif juga dibantu dengan menggunakan tabel serta grafik untuk memperjelas mengenai seberapa besar pertumbuhan yang ada sesuai dengan data dan fakta yang tercantum Variabel independen (X) pada penelitian ini adalah inflasi (X1), nilai tukar Rupiah terhadap USD (X2), dan BI rate (X3) sebagai faktor yang akan diteliti bagaimana pengarunya terhadap variabel dependan (Y). Populasi yang diambil dalam penelitian ini adalah nilai emisi sukuk korporasi perusahaan - perusahaan yang menerbitkan sukuk korporasi dan terdaftar di Jakarta Islamic Index (JII) sebanyak 60 sampel diambil di dalam penelitian ini. Data yang digunakan di dalam penelitian ini bersifat kuantitatif yang dipublikasikan oleh Otoritas Jasa Keuangan (OJK) 2014-2018, Bank Indonesia (BI) 2014-2018, dan Badan Pusat Statistika (BPS) 2014-2018, yaitu data yang dicantumkan dalam bentuk angka - angka. Data yang digunakan di dalam penelitian ini juga merupakan data sekunder. Teknik analisis data yang digunakan oleh penulis dalam penelitian ini adalah analisis regresi linier berganda dengan menggunakan beberapa uji diantaranya adalah Uji Asumsi Klasik dengan Uji Normalitas, Uji Autokorelasi, Uji Heterokedastisitas, dan Uji Multikolinieritas. Lalu Uji Kriteria Statistika dengan Uji Koefisien Determinasi $\left(\mathrm{R}^{2}\right)$, dan Uji t Parsial. Yang terakhir adalah Uji Kriteria Ekonomi, evaluasi model ini dilakukan untuk membandingkan kesesuaian antara nilai estimator dengan teori ekonomi yang ada dan juga dengan 
logika. Pengaruh variabel. X terhadap variabel Y harus dijelaskan dengan penjelasan ekonomi.

\section{Hasil dan Pembahasan}

\section{Uji Asumsi Klasik}

1. Uji Normalitas

Uji normalitas dilakukan dengan menggunakan metode Kolmogorov-Smirnov Test yang terdapat di dalam aplikasi pengolah data SPSS.

Tabel. 2 Uji Normalitas

\begin{tabular}{|c|c|c|}
\hline \multicolumn{3}{|c|}{ One-Sample Kolmogorov-Smirnov Test } \\
\hline & & Unstandardized Residual \\
\hline \multicolumn{2}{|l|}{$\mathrm{N}$} & 60 \\
\hline \multirow[t]{2}{*}{ Normal Parameters } & Mean & .0000000 \\
\hline & Std. Deviation & 2.26607245 \\
\hline \multirow[t]{3}{*}{ Most Extreme Differences } & Absolute & .095 \\
\hline & Positive & .095 \\
\hline & Negative & -.083 \\
\hline \multicolumn{2}{|l|}{ Test Statistic } &.$/ 95$ \\
\hline \multicolumn{2}{|l|}{ Asymp. Sig. (2-tailed) } & $.200^{\mathrm{c}, \mathrm{d}}$ \\
\hline \multicolumn{3}{|l|}{ a. Test distribution is Normal. } \\
\hline \multicolumn{3}{|c|}{ b. Calculated from data. } \\
\hline \multicolumn{3}{|c|}{ c. Lilliefors Significance Correction. } \\
\hline
\end{tabular}

Sumber: data sekunder yang diolah, 2020.

Hal diatas menunjukan bahwa data terdistribusi dengan normal karena nilai Asymp. Sig. (2tailed)nya $>0,05$ dimana taraf nyata $\alpha=5$ persen maka tidak cukup bukti untuk melakukan penolakan terhadap $\mathrm{H} 0$, sehingga residual berdistribusi normal.

2. Uji Autokorelasi

Pengujian autokorelasi di dalam spss dilakukan dengan menggunakan autokorelasi DurbinWatson dan metode Cochrane Orcutt.

Tabel 3. Uji Autokorelasi

\begin{tabular}{|c|c|c|c|c|c|}
\hline \multicolumn{6}{|c|}{ Model Summary $^{\mathrm{b}}$} \\
\hline Model & $\mathrm{R}$ & R Square & $\begin{array}{c}\text { Adjusted R } \\
\text { Square }\end{array}$ & $\begin{array}{l}\text { Std. Error of } \\
\text { the Estimate }\end{array}$ & $\begin{array}{l}\text { Durbin- } \\
\text { Watson }\end{array}$ \\
\hline 1 & $.251^{a}$ & .063 & .012 & 1.79386 & 1.670 \\
\hline \multicolumn{6}{|c|}{ a. Predictors: (Constant), Lag_BIRate1, Lag_Inflasi1, Lag_Nilai'Tukar1 } \\
\hline \multicolumn{6}{|c|}{ b. Dependent Variable: Lag_Emisi1 } \\
\hline
\end{tabular}

Sumber: data sekunder yang diolah, 2020.

Hasil uji autokorelasi yang didapatkan dari pengujian ini menghasilkan angka Durbin-Watson sebesar 1,670 yang menunjukan bahwa data tersebut tidak memiliki gejala autokorelasi karena menghasilkan $-2<1,670<2$. Sesuai dengan teori autokorelasi menurut Singgih Santoso.

3. Uji Heterokedastisitas

Pengujian heterokedastisitas di dalam spss dilakukan dengan menggunakan metode uji glejser dengan menggunakan trnasformasi data ke Ln. 
Tabel 4. Uji Heterokedastisitas

\begin{tabular}{|c|c|c|c|c|c|}
\hline \multicolumn{6}{|c|}{ Coefficients $^{\mathrm{a}}$} \\
\hline \multirow[b]{2}{*}{ Model } & \multicolumn{2}{|c|}{ Unstandardized Coefficients } & \multirow{2}{*}{$\begin{array}{c}\begin{array}{c}\text { Standardized } \\
\text { Coefficients }\end{array} \\
\text { Beta }\end{array}$} & \multirow[b]{2}{*}{$\mathrm{T}$} & \multirow[b]{2}{*}{ Sig. } \\
\hline & $\mathrm{B}$ & Std. Error & & & \\
\hline (Constant) & -14.020 & 21.219 & & -.661 & .514 \\
\hline LN_Inflasi & .203 & .455 & .104 & .447 & .659 \\
\hline LN_NilaiTukar & 1.509 & 2.307 & .156 & .654 & .519 \\
\hline LN_BIRate & -.345 & .192 & -.341 & -1.793 & .084 \\
\hline
\end{tabular}

Sumber: data sekunder yang diolah, 2020.

Hasil uji heterokedastisitas yang didapatkan dari pengujian ini menghasilkan angka Sig. dari seluruh variabel melebihi atau $>0,05$ yang berarti data tersebut tidak memiliki gejala heterokedastisitas.

4. Uji Multikolinieritas

Pengujian multikolinieritas di dalam spss dilakukan dengan cara melihat nilai tolerance dan variance inflating factor (VTF).

Tabel 5. Uji Multikolinieritas

\begin{tabular}{|c|c|c|c|c|c|c|c|}
\hline \multicolumn{8}{|c|}{ Coefficients $^{a}$} \\
\hline \multirow[b]{2}{*}{ Model } & \multicolumn{2}{|c|}{$\begin{array}{c}\text { Unstandardized } \\
\text { Coefficients }\end{array}$} & \multirow{2}{*}{$\begin{array}{c}\text { Standardized } \\
\text { Coefficients } \\
\text { Beta } \\
\end{array}$} & \multirow[b]{2}{*}{$\mathrm{t}$} & \multirow[b]{2}{*}{ Sig. } & \multicolumn{2}{|c|}{ Collinearity Statistics } \\
\hline & B & $\begin{array}{l}\text { Std. } \\
\text { Error }\end{array}$ & & & & Tolerance & VIF \\
\hline (Constant) & -9.351 & 6.211 & & -1.505 & .138 & & \\
\hline LN_Inflasi & -47.121 & 21.655 & -.295 & -2.176 & .034 & .684 & 1.461 \\
\hline $\begin{array}{l}\text { LN_Nilai } \\
\text { Tukar }\end{array}$ & .001 & .000 & .325 & 2.380 & .021 & .674 & 1.483 \\
\hline $\begin{array}{l}\text { LN_BI } \\
\text { Rate }\end{array}$ & -.295 & 4.769 & -.007 & -.062 & .951 & .970 & 1.031 \\
\hline a. Depende & Variable & [_Emisi & & & & & \\
\hline
\end{tabular}

Sumber: data sekunder yang diolah, 2020.

Dari hasil pengujian didapatkan nilai tolerance seluruh variabel lebih besar dari 0,10 dan nilai VIF seluruh variabel kurang dari 10,00 itu artinya tidak terjadi multikolinieritas dalam model regresi tersebut.

\section{Uji Kriteria Statistika}

1. Uji Koefisien Determinasi $\left(\mathrm{R}^{2}\right)$

Koefisien determinasi pada intinya mengukur seberapa jauh kemampuan sebuah model dalam menerangkan variasi variabel Dependen, dengan kata lain mengukur seberapa jauh kemampuan model dalam menerangkan variabel Inflasi, Nilai Tukar, dan BI rate. 
Tabel 6. Uji Koefisien Determinasi $\left(\mathrm{R}^{2}\right)$

\begin{tabular}{|c|c|c|c|c|}
\hline \multicolumn{5}{|c|}{ Model Summary } \\
\hline Model & $\mathrm{R}$ & R Square & $\begin{array}{c}\text { Adjusted R } \\
\text { Square }\end{array}$ & $\begin{array}{c}\text { Std. Error of the } \\
\text { Estimate }\end{array}$ \\
\hline 1 & $.545^{\mathrm{a}}$ & .298 & .260 & 2.32598 \\
\hline \multicolumn{2}{|l|}{ a. Predictors: (Constant), BI Rate, Inflasi, Nilai Tukar } \\
\hline
\end{tabular}

Sumber: data sekunder yang diolah, 2020.

Berdasarkan hasil analisis data diperoleh nilai koefisien determinasi $\left(\mathrm{R}^{2}\right)$ yaitu sebesar 0,298 yang artinya 0,298 variabel terikat Emisi Sukuk Koporasi dijelaskan oleh variabel bebas yang terdiri dari Inflasi, Nilai Tukar, dan BI rate, sisanya dijellaskan oleh variabel lain di luar variabel-variabel yang dianalisis.Dengan kata lain sebagian besar variabel terikat dijelaskan oleh variabel-variabel bebas yang tidak digunakan dalam model regresi yang dianalisis.

\section{Uji t Parsial}

Uji Statistik adalah salah satu test statistik yang dipergunakan untuk menguji kebenaran atau kepalsuan hipotesis nihil yang menyatakan bahwa diantara dua buah mean sampel yang diambil secara random dari populasi yang sama, tidak terdapat perbedaan yang signifikan.

Tabel 7. Uji t Parsial

\begin{tabular}{|c|c|c|c|c|c|}
\hline \multicolumn{6}{|c|}{ Coefficients $^{\mathrm{a}}$} \\
\hline \multirow[b]{2}{*}{ Model } & \multicolumn{2}{|c|}{ Unstandardized Coefficients } & \multirow{2}{*}{$\begin{array}{c}\text { Standardized } \\
\text { Coefficients } \\
\text { Beta }\end{array}$} & \multirow[b]{2}{*}{$\mathrm{T}$} & \multirow[b]{2}{*}{ Sig. } \\
\hline & $\mathrm{B}$ & Std. Error & & & \\
\hline (Constant) & -9.351 & 6.211 & & -1.505 & .138 \\
\hline LN_Inflasi & -47.121 & 21.655 & -.295 & -2.176 & .034 \\
\hline $\begin{array}{l}\text { LN_Nilai } \\
\text { Tukar }\end{array}$ & .001 & .000 & .325 & 2.380 & .021 \\
\hline LN_BI Rate & -.295 & 4.769 & -.007 & -.062 & .951 \\
\hline
\end{tabular}

Sumber: data sekunder yang diolah, 2020.

Berdasarkan hasil analisis uji statistik t diatas diketahui nilai Signifikansi (Sig) variabel inflasi adalah sebesar $0,034<$ probabilitas 0,05 , dan berdasarkan perbandingan nilai $\mathrm{t}$ hitung dengan $\mathrm{t}$ tabel didapatkan hasil -2,176 <-1,67252 < 1,67252 maka dapat disimpulkan bahwa H1 atau hipotesis pertama ditolak. Artinya ada pengaruh negatif (signifikan) terhadap volume pertumbuhan emisi sukuk korporasi di Indonesia. Untuk variabel Nilai Tukar menghasilkan nilai sebesar 0,021 < probabilitas sebesar 0,05 , dan berdasarkan perbandingan nilai t hitung dengan $t$ tabel didapatkan hasil 2,380 > 1,67252 maka dapat disimpulkan bahwa H2 atau hipotesis kedua ditolak, karena ada pengaruh positif (signifikan terhadap volume pertumbuhan emisi sukuk korporasi di Indonesia. Lalu untuk variabel BI Rate menghasilkan nilai signifikansi sebesar $0,951>$ probabilitas 0,05 , dan berdasarkan perbandingan nilai $\mathrm{t}$ hitung dengan t tabel didapatkan hasil -0,062 > -1,67252< 1,67252 yang berarti H3 atau hipotesis 3 ditolak karena tidak ada pengaruh signifikan terhadap volume pertumbuhan emisi sukuk korporasi di Indonesia. 


\section{Uji Kriteria Ekonomi}

1. Pengaruh inflasi terhadap volume pertumbuhan emisi sukuk korporasi di Indonesia

Variabel inflasi berpengaruh negatif signifikan pada taraf nyata 5\% terhadap volume pertumbuhan sukuk korporasi di Indonesia dan memiliki nilai signifikansi sebesar 0,034 yang artinya jika terjadi kenaikan inflasi sebesar 5\% maka akan menyebabkan penurunan volume sukuk korporasi di Indonesia sebesar $0,034 \%$. Hal ini memperlihatkan bahwa jika terjadi kenaikan inflasi maka masyarakat cenderung tidak akan menginvestasikan uangnya melalui sukuk korporasi, karena adanya kenaikan harga yang bisa menurunkan profitabilitas perusahaan dan menyebabkan return atau keuntungan yang akan didapatkan investor menjadi sedikit. Hasil penelitian ini sejalan dengan penelitian yang dilakukan oleh (Rini, 2012) dimana inflasi berpengaruh negative signifikan terhadap pertumbuhan sukuk korporasi, namun penelitian ini tidak sejalan dengan (Kurniawan, Masitoh, \& Fajri, 2020) dimana inflasi berpengaruh positif terhadap pertumbuhan sukuk korporasi di Indonesia.

2. Pengaruh nilai tukar terhadap volume pertumbuhan emisi sukuk korporasi di Indonesia

Variabel nilai tukar berpengaruh positif signifikan pada taraf nyata 5\% terhadap volume pertumbuhan sukuk korporasi di Indonesia dan memiliki nilai signifikansi sebesar 0,021 yang artinya jika terjadi kenaikan nilai tukar sebesar 5\% maka akan menyebabkan pertumbuhan volume sukuk korporasi di Indonesia meningkat sebesar 0,021\%. Hal ini memperlihatkan bahwa jika nilai rupiah terhadap USD semakin rendah atau terdepresiasi maka masyarakat akan lebih memilih menginvestasikan uangnya pada sukuk korporasi, karena orang tidak akan memborong untuk membeli US\$, lebih baik mengalokasikannya pada pembelian sukuk. Kepekaan perubahan nilai tukar terhadap pertumbuhan volume sukuk korporasi cukup sensitif, karena seperti yang bisa dilihat pada data nilai tukar selama tahun 2014 - 2018 nominalnya mengalami fluktuasi walaupun tidak terlalu signifikan. Hal ini tentu akan berdampak pada volume pertumbuhan emisi sukuk korporasi. Hasil penelitian ini tidak sejalan dengan penelitian yang dilakukan oleh (Ardiansyah \& Lubis, 2017) karena di dalam penelitian tersebut menghasilkan bahwa nilai tukar berpengaruh negatif signifikan terhadap pertumbuhan sukuk korporasi di Indonesia.

3. Pengaruh BI Rate terhadap volume pertumbuhan emisi sukuk korporasi di Indonesia

Variabel BI Rate tidak berpengaruh signifikan pada taraf nyata 5\% terhadap volume pertumbuhan sukuk korporasi di Indonesia dan memiliki nilai signifikansi sebesar 0,951 yang artinya jika terjadi kenaikan nilai tukar sebesar 5\% maka tidak akan berpengaruh terhadap pertumbuhan volume sukuk korporasi di Indonesia. Hal ini ternyata perubahan yang dialami oleh BI Rate hanya mempengaruhi investasi di pasar uang saja, dan tidak mempengaruhi investasi di pasar modal.

\section{Penutup}

Berdasarkan penelitian dan analisis yang sudah dilakukan, serta perumusan masalah dan tujuan maka dapat disimpulkan bahwa:

1. Laju inflasi berpengaruh negatif signifikan terhadap volume pertumbuhan emisi sukuk korporasi di Indonesia.

2. Nilai tukar berpengaruh positif signifikan terhadap volume pertumbuhan emisi sukuk korporasi di Indonesia.

3. BI Rate tidak berpengaruh terhadap volume pertumbuhan emisi sukuk korporasi di Indonesia.

Perubahan di dalam dunia investasi tidak terlepas dari faktor - faktor yang mempengaruhinya, terutama faktor makroekonomi. Secara khusus pertumbuhan ekonomi akan memberikan perubahan terhadap investasi entah itu perubahan yang berbahaya maupun perubahan yang 
menjadikan pertumbuhan investasi menjadi lebih baik. Maka dari itu perlu adanya stabilisasi pertumbuhan ekonomi guna pertumbuhan investasi di Indonesia menjadi lebih baik, semakin kesini pasar modal syariah sudah mulai menunjukan eksistensinya dan mulai menunjukan pertumbuhan yang cukup besar, maka dari itu perlu adanya perhatian yang lebih atau khusus untuk pasar modal syariah khususnya sukuk korporasi, karena sukuk korporasi merupakan salah satu alternatif investasi di pasar modal yang menjanjikan.

\section{Daftar Pustaka}

Anoraga, Pandji dan Pakarti Piji. (2001). Pengantar Pasar Modal, Edisi Revisi. Jakarta: Mahasatya.

Ardiansyah, I. H., \& Lubis, D. (2017). Pengaruh Variabel Makroekonomi terhadap Pertumbuhan Sukuk Korporasi di Indonesia. Al-Murara'ah, 5, 66.

Hariyanto, E. (2017). Evaluasi Kebijakan Penerbitan Sukuk Negara, Sebagai Instrumen Pembiayaan $A P B N$. Yogyakarta: Gava Media.

Kurniawan, Masitoh, E., \& Fajri, R. N. (2020). Pengaruh Variabel Makroekonomi Terhadap Pertumbuhan Sukuk Korporasi di Indonesia. FINANSLA: Jurnal Akuntansi dan Perbankan Syariah, 3, 81.

Manan, A. (2009). Aspek. Hukum dalam Penyelenggaraan Investasi di Pasar Modal Syariah. Jakarta: Kencana.

Mankiw, G. N. (2007). Pengantar Ekonomi Makro (Edisi Asia) (6 ed.). (B. B. Alkemis, Trans.) Jakarta: Erlangga.

Rahmawati, R., \& Djatnika, D. (2020). Analisis Pengaruh Pembiayaan Syariah dan Variabel Makro Ekonomi Terhadap Ekspor Indonesia (Studi Pada BUS Devisa dan LPEI). Journal of Applied Islamic Economics and Finance, 1(1), 23-36.

Rini, M. (2012). Obligasi Syariah (Sukuk) dan Indikator Makroekonomi Indonesia, Sebuah Analisis Vector Error Correction Model. Iqtishodia Jurnal Ekonomi Islam Republike a, 2, 87-104.

Siamat, D. (2005). Manajemen Lembaga Keuangan "Kebijakan Moneter dan Perbankan". Jakarta: Fakultas Ekonomi Universitas Indonesia.

Suta, I. G. (2000). Menuju Pasar Modal Moderen. Jakarta: Yayasan SAD Satria Bakti.

Tripuspitorini, F. A., \& Setiawan, S. (2020). Pengaruh faktor makroekonomi terhadap pertumbuhan dana pihak ketiga pada bank umum syariah di Indonesia. Jurnal Riset Akuntansi dan Keuangan, 8(1), 121-132. 